\title{
Penerapan Rinfo Form Sebagai Media Pengumpulan Data Hasil Kinerja Dosen iLearning
}

\author{
Indri Handayani, S.Kom ${ }^{1}$ \\ Siti Mutmainah ${ }^{2}$ \\ Olis Rosmawati ${ }^{3}$
}

\author{
Jl. Jendral Sudirman No. 40, Modernland Tangerang \\ indri@raharja.info siti.mutmainah@raharja.info ${ }^{2)}$, olis@ raharja.info $^{3)}$
}

\begin{abstract}
ABSTRAK
Survey online merupakan hal yang penting bagi Perguruan Tinggi Raharja, dikarenakan dari survey online tersebut kita bisa mengetahui hasil kinerja para dosen yang ada. Dan sistem kuesioner sebelumnya masih menggunakan Sistem yang manual. Sistem ini masih menggunakan media kertas yang harus diambil dari RPU oleh petugas kuesioner, lalu petugas kuesioner akan memberikan lembar kuesioner ke kelas-kelas dan diberikan kepada mahasiswa untuk diisi . Hal itu membuat tidak efektif dan tidak efisiennya cara menilai hasil kinerja Dosen di Perguruan Tinggi Raharja, karena Kuisioner secara manual membutuhkan waktu yang lama dari cara pembuatan, pencetakkan, penyebaran, dan penginputan hasil Form Kuesioner tersebut. Karena saat Form Kuesioner telah diisi oleh mahasiswa, Petugas akan memberikan hasil Form Kuesioner kepada RPU dan RPU akan menginput satu persatu Form Kuisioner dengan menggunakan Microsoft Exel, hal itu dapat memungkinkan terjadinya Human Error. Berdasarkan kekurangan diatas maka Perguruan Tinggi Raharja mengubah kuesioner dosen manual dengan Rinfo Form, Rinfo Form merupakan sistem yang berguna untuk membuat form online, form pembayaran, dan juga form voting secara online. Dan yang sangat penting Rinfo Form ini sudah SSO (single sign on) dengan Google dengan begitu mahasiswa lebih mudah untuk mengisi Kuesioner secara online. Rinfo Formjuga menggunakan Form Emailer jadi saat mahasiswa sudah selesai mengisi form tersebut, maka secara otomatis mahasiswa akan mendapatkan email pemberitahuan karena sudah mengisi form tersebut, dan admin pun akan mendapat email pemberitahuan dari siapa saja yang sudah mengisi kuesioner online tersebut, Rinfo Form juga sudah terhubung dengan spreadsheet dengan begitu admin lebih mudah untuk merekap data yang sudah masuk.
\end{abstract}

Kata kunci : Kuesioner Online, Rinfo Form, Rinfo Sheet

ABSTRACT 
Online Survey is important for College Prog, because of the online survey we can find out the result of the perfomance of the lecturers there. And the system is still using the previous Questionnaire System Manual. This System still uses Media Paper to be taken from the RPU by the Officer Questionnaire, and Officers Questionnaires will give questionnaire sheet to the classes and given to students to fill out. It made ineffetive and inefficient way of assesing the perfomance result Lecturer at the College of Prog, because the questionnaire was manually take a long time on how to manufacture, print, deployment, and inputting the result of the questionnaire form. Because whe the Form Questionnaire were completed by Studen Officer will provide the result to the Questionnaire Form and RPU. RPU will enter one by one Form Questionnaire by using Microsoft Exel, it can allow the occurrence of Human Error. Based on the above the shortage of Higher Education Prog manually change the questionnaire lecturer with Rinfo Form. Rinfo Form a useful system to create an online form, form a payment, and also create an online voting form. And that is very important Rinfo Form is already SSO(single sign on) with Google so student are easier to fill out an online questionnaire. Rinfo Form also use Form Emailer so when the students have finished completing the form, then automatically the student will get an email notification because it fills out the form and the Admin will receive an email notification from anyone who have already filled out questionnaires online, the Rinfo Form also spreadsheet are connected with the so admins easier to recapitalize the data that has been entered.

Keywords : Online Questionnaire, Form Rinfo,Rinfo Sheet

\section{PENDAHULUAN}

Google Form atau yang lebih dikenal dengan Rinfo Form pada Perguruan Tinggi Raharja adalah salah satu fitur yang terdapat didalam Google. Perguruan Tinggi Raharja sangat meningkatkan peranan teknologi, hal itu yang membuat para pribadi Raharja berusaha dalam mengatasi segala permasalahan yang ada sehingga para pribadi Raharja diharapkan dapat memiliki kemampuan untuk menciptakan atau mengembangkan suatu sistem yang dapat berguna dan memudahkan para Staff maupun Dosen yang berada di dalam Lingkungan Perguruan Tinggi Raharja, untuk melakukan survey online dan merekap hasil survey tersebut dalam waktu yang efektif dan efisien.

Perguruan Tinggi Raharja membutuhkan suatu sistem kuesioner online yang mudah digunakan dalam melakukan survey online untuk dapat digunakan oleh Para Pribadi Raharja. Sebuah sistem Rinfo Form tersebut nantinya diharapkan menjadi jalan keluar yang baik Sebuah sistem Rinfo Form tersebut nantinya diharapkan menjadi jalan keluar yang baik dalam bdalam berjalannya kuesioner online yang digunakan oleh Dosen dan Mahasiswa. 
Rinfo Form adalah awal dari kerangka pengupulan data yang sangat serba guna, pada jaman seperti ini memang dibutuhkan fasilitas-fasilitas modern untuk memudahkan akses informasi. Permasalahan kuesioner online pada Perguruan Tinggi Raharja adalah masih terdapat kegiatan akademik di Perguruan Tinggi Raharaja yang melaksanakan survey secara manual serta masih terdapat kegiatan akademik yang membutuhkan adanya survey untuk menilai sistem pelayanan yang mereka jalankan atau untuk melakukan pemilihan terhadap sesuatu namun belum pernah menggunakan metode survey secara online. Pandangan orang lain tentang metode survey online selalu nampak sulit karena menggunakan PC atau Gadget untuk mengisinya, dan juga banyaknya fitur-fituryang tidak mereka ketahui kegunaannya untuk apa. tetapi tidak untuk sistem Rinfo Form ini karena Rinfo Form memberikan kemudahan kepada pengguna karena Rinfo Form sudah SSO dengan Google. Dengan tersedianya SSO dengan Google dan juga dengan menggunakan Form Emailer ini diharapkan memberikan kemudahan kepada Para Pribadi Raharja yang telah melakukan survey online.

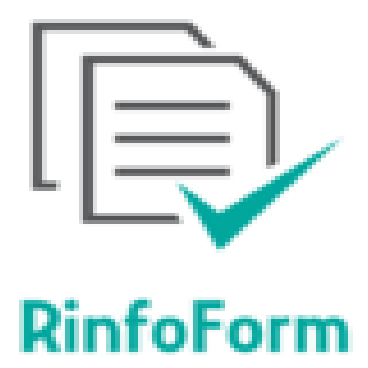

Gambar 1. Logo Rinfo Form

Warna hijau tosca pada logo Rinfo Form diatas melambangkan kesejukan,elegant, dan kuat diibaratkan pemikiran sudah terlihat matang dan siap mengambil keputusan. Lalu gambar form yang diceklis adalah melambangkan Rinfo Form itu sendiri, arti dari ceklis itu melambangkan survey, dan warna hijau tosca pada ceklis nitu melambangkan pertumbuhan, pertumbuhan yang dimaksud adalah Rinfo Form selalu tumbuh dan berkembang di Perguruan Tinggi Raharja.

\section{PERMASALAHAN}

Pada Perguruan Tinggi Raharja saat ini memiliki Tiga Program cara pembelajaran yaitu, Pembelajaran Reguler, Pembelajaran iLearning, dan Pembelajaran ILP (iLearning Plus). Pada pembelajaran iLearning Mahasiswa akan mendapatkan assigment kuisioner secara online dari Dosen yang mengajar tetapi, pada Pembelajaran Reguler Mahasiswa akan diberikan kuesioner secara manual oleh Petugas Kuesioner yang diberikan lembaran kuesioner oleh RPU untuk dibagikan kekelas-kelas. dan dalam hal ini terdapat 5 permasalahan, permasalahan yang pertama yaitu sistem yang 
digunakan masih manual dan memakan waktu yang cukup lama untuk pembuatan Form Kuesioner Dosen tersebut dan setelah itu Form di cetak satu persatu. permasalahan yang kedua, Petugas mengambil lembaran kuesioner ke RPU dan Petugas membagikan Kuesioner tersebut ke kelas-kelas. Permasalahan ketiga, RPU harus menginput satu persatu kuesioner yang telah diisi tersebut menggunakan Microsoft Exel hal ini yang bisa memungkinkan terjadinya Human Error dalam penginputan data Kuisioner dosen tersebut.

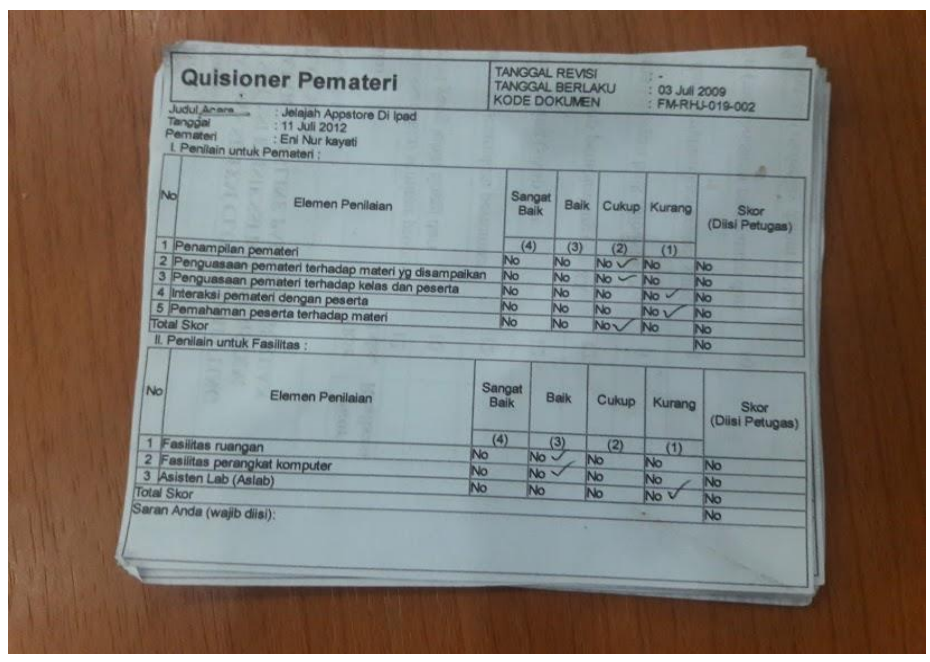

Gambar 2. Kuesioner Dosen Kelas Reguler

Gambar diatas adalah kuesioner dosen kelas reguler yang masih menggunakan sistem manual, yang dibagikan oleh petugas kuesioner, dan diisi oleh para mahasiswa. Gambar diatas terdiri dari kolom elemen penilaian, sangat baik, baik, cukup, kurang, skor (yang diisi petugas) dan kolom saran.

Setelah pembagian masih adanya mahasiswa yang tidak mengisi form kuesioner tersebut, ada mahasiswa yang hanya mengisi beberapa pertanyaan bahkan ada mahasiswa yang sama sekali tidak mengisi form kuesioner tersebut. Karena pada saat pembagian form kuesioner dosen tersebut dosen atau petugas tidak memantau satu per satu mahasiswa yang mengisi form kuesioner tersebut, setelah selesai mengisi mahasiswa memberikan form kuesioner kepada petugas, dan petugaspun merapihkan lembaran form kuesioner tersebut lalu memberikan kepada RPU untuk direkap satu persatu kedalam microsoft exel.

Hal ini yang membuat tidak efektif dan efisiennya kuesioner manual, karena menghabiskan banyak waktu dan banyak kertas yang digunakan. Dan setelah diinput oleh RPU, form kuesioner dosenpun tidak terpakai dan hanya disimpan di lemari data kuesioner dosen. Hal ini selalu terjadi setiap tahunnya yang membuat ruangan tidak tertata dengan rapi karena banyaknya tumpukkan data kuesioner dosen. 


\section{METODE PENELITIAN}

Literature review adalah bahan yang tertulis berupa buku, jurnal yang membahas tentang topik yang hendak diteliti ([Menurut Hermawan 2009:45]). Banyak penelitian yang sebelumnya dilakukan mengenai Rinfo Form. Dalam sistem Rinfo Form ini perlu dilakukan studi pustaka sebagai salah satu dari penerapan metode penelitian yang akan dilakukan.Berikut ini adalah 6 penelitian yang telah dilakukan dan memiliki kolerasi yang searah dengan penelitian yang akan dibahas dalam Jurnal ini diantaranya :

1. Penelitian yang dilakukan oleh Kenney (2011) yang berjudul "Using Google Forms to Schedule Classes in Your Library". Penelitian ini menggunakan Google form adalah cara yang bagus untuk mengumpulkan informasi dari pengunjung. Si penulis menjelaskan penggunaan Google bentuk seperti kunjungan kelas penjadwalan alat untuk mengumpulkan informasi tentang potensi kelas media center dan mempublikasikan berbagai layanan dan sumber daya yang tersedia. Bentuk penjadwalan a time saver untuk guru dan pustakawan yang sama dan informasi yang diterima melalui itu jauh lebih unggul untuk informasi yang dikumpulkan melalui e-mail.[1]

2. Penelitian dilakukan oleh Laura Taylor dan Kirsten Doehler (2014) yang berjudul "Using online survey to promote and assess learning". Penelitian ini digunakan untuk membuat sebuah survey online yang dipakai oleh siswa/i untuk mengumpulkan sebuah data dari siswa/i yang masih ada jam kelas. Penulis juga menggunakan sebuah perangkat lunak survey online untuk keperluan lain seperti mengumpulkan penilaian informasi dan mahasiswa preferensi yang berhubungan dengan proyek-proyek statistik. [2]

3. Penelitian dilakukan oleh Andri Heryandi (2012) yang berjudul "Pembangunan Sistem Informasi Pengisian Survey Evaluasi Perkuliahan Online di Universitas Komputer Indonesia” Penjaminan mutu merupakan suatu hal yang penting dilakukan pada suatu perguruan tinggi. Universitas Komputer Indonesia (UNIKOM) telah beberapa tahun melakukan proses penjaminan mutu yang salah satunya menggunakan instrument berupa kuesioner. Kuesioner ini digunakan untuk mengevaluasi proses perkuliahan yang telah berlangsung. Setiap mahasiswa mengisi kuesioner berdasarkan matakuliah-matakuliah yang diambil ketika perwalian. Data kuesioner yang telah diisi mahasiswa kemudian dapat diakses melalui Sistem Informasi Evaluasi Perkuliahan (SIMEP). Tetapi sistem yang berjalan sekarang mempunyai kelemahan yaitu cara pengisian kuesioner yang manual. Kelemahan tersebut mengakibatkan lamanya proses pemasukkan data dan kekurangakuratan data yang diinputkan. Oleh karena itu dibangun suatu sistem untuk melakukan pengisian kuesioner secara online. Dengan adanya sistem ini, diharapkan pengisian kuesioner dapat dilakukan dengan lebih cepat dan akurat. Sistem ini dibangun berbasis web dan menjadi bagian dari sistem perwalian online. [3] 
4. Penelitian yang dilakukan oleh Banias dalam karya ilmiah dengan judul "Can we use sport, web 2.0 and social \& informal learning to develop \& enhance social competences?". Penelitian ini membahas tentang kuesioner online menggunakan google form untuk menganalisis hubungan antara olahraga, media sosial dan pencapaian informal maupun formal. Kompetensi yang dirancang menggunakan google form karena mudah digunakan, bebas untuk menggunakan dan yang lebih penting familiar bagi responden. Google form dalam penelitian ini sebagai aplikasi survei dengan cara dibagikan melalui email yang mencantumkan link dan link tersebut sudah tercantum pada website dari platform pembelajaran [4]

5. Penelitian yang dilakukan oleh Reny Sari Dewi, A. Holil Noor Ali, dan Hanim Maria Astuti (2012) dalam karya ilmiah yang berjudul "Analisis Pengaruh Kualitas Informasi pada Kuesioner Indeks Pengajar Dosen Online Terhadap Kepuasan Pengguna" Kualitas informasi pada kuesioner IPD online dapat diketahui dari empat faktor, yaitu intrinsik, kemampuan akses, kontekstual, dan representasi datanya. Sedangkan kepuasan penggunanya ditentukan oleh kesesuaian informasi, kemudahan akses, komponen informasi, dan tampilan informasi tersebut. Penelitian ini adalah penelitian kuantitatif dan kualitatif, berdasarkan sampel acak berjumlah 113 orang responden mahasiswa dan 30 orang responden dosen. Hal ini disebabkan oleh tingkat pemahaman mahasiswa atau dosen berdasarkan sering tidaknya mengakases kuesioner IPD online. Alat bantu analisis yang digunakan adalah SPSS versi 17.0 dengan menggunakan fungsi analisis faktor dan korelasi untuk pengujian hipotesisnya. Hasil analisis faktor secara keseluruhan memenuhi kriteria kecukupan data yang valid. Sehingga hasil dari pereduksian atau pemfaktoran tersebut dikorelasikan dengan kepuasan penggunanya, yaitu mahasiswa dan dosen. Dari data hasil analisis, terlihat bahwa dari kedua hipotesis diterima yaitu: (1) Kualitas informasi pada kuesioner IPD online berpengaruh positif terhadap kepuasan mahasiswa, (2) Kualitas informasi pada kuesioner IPD online berpengaruh positifterhadap kepuasan dosen. Dari hasil pengujian hipotesis tersebut, maka dapat dirumuskan beberapa rekomendasi perbaikan yang berupa implikasi manajerial sebagai langkah peningkatan kualitas informasinya. [5]

6. Penelitian yang dilakukan oleh Kartika (2015) dengan judul penelitian yaitu "Penerapan Technology Acceptance Model pada Aplikasi Edmodo di Universitas Ciputra Surabaya menggunakan Analisis Jalur”. Dalam peneitian ini peneliti ingin melihat bagaimana TAM (Technology Acceptance Model) dari Edmodo yang sudah diterapkan dengan metode Analisis Jalur (Path Analysis) dengan menggunakan google form sebagai form kuesioner dan telah mendapat responden sebanyak 165 mahasiswa dari berbagai jurusan yang ada di Universitas Ciputra. Edmodo merupakan salah satu aplikasi yang digunakan di 
Universitas Ciputra Surabaya dalam mengkoordinasikan jadwal serta berkomunikasi antara dosen dengan mahasiswa. [6]

7. Penelitian yang dilakukan oleh Jumar Slamet dengan judul "Otak-Atik Google Form Guna Pembuatan Kuesioner Kepuasan Pemustaka”. Penelitian ini membahas pemanfaatan Google form untuk kuesioner sebagai pengukuran tingkat kepuasan pemustaka terhadap layanan perpustakaan. Kuesioner kepuasan pemustaka yang dibuat dan di share melalui Google form dapat diakui sebagai langkah positif guna pendukung kebutuhan informasi dari pemustaka. [7]

Dari ke-7 (Tujuh) literature riview yang terdapat diatas telah banyak penelitian mengenai penggunaan Google Form atau Rinfo Form untuk kegiatan kuesioner akademik secara online, terdiri dari 5 (lima) literature review membahas tentang Rinfo berkaitan dengan kuesioner online dan terdiri dari 2 (dua) literature review membahas penggunakan Google form berkaitan dengan penerapan Rinfo form dalam penelitian ini. Telah banyak penelitian mengenai pengunaan Google form.

\section{PEMECAHAN MASALAH}

Untuk mengatasi berbagai macam masalah tersebut, maka diperlukan sistem yang efektif dan efisien dalam melakukan pengisian kuesioner secara online. Dari rumusan masalah tersebut menghasilkan 1 pemecahan masalah yaitu dengan menggunakan Rinfo Form, maka diharapkan sistem kuisioner online dengan menggunakan Rinfo Form ini bisa lebih memudahkan mahasiswa untuk menilai hasil kinerja Dosen tersebut. Dan Dosen pun bisa lebih mudah untuk memberikan Form Online ini kepada Mahasiswa yang diajarnya. Dan juga dengan menggunakan Rinfo Form ini admin bisa lebih mudah untuk merekap hasil kuesioner online tersebut dengan menggunakan Spreadsheet yang langsung terhubung dari Rinfo Form dan juga Form emailer.

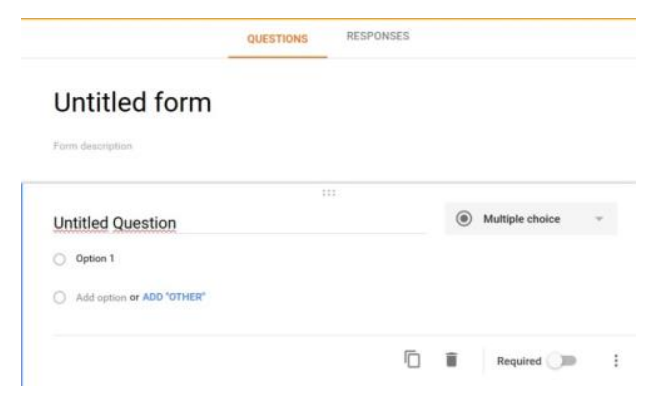

Gambar 3 . Tampilan awal Rinfo Form

Rinfo Form adalah salah satu aplikasi dari Google yang bermanfaat untuk membuat berbagai macam form 


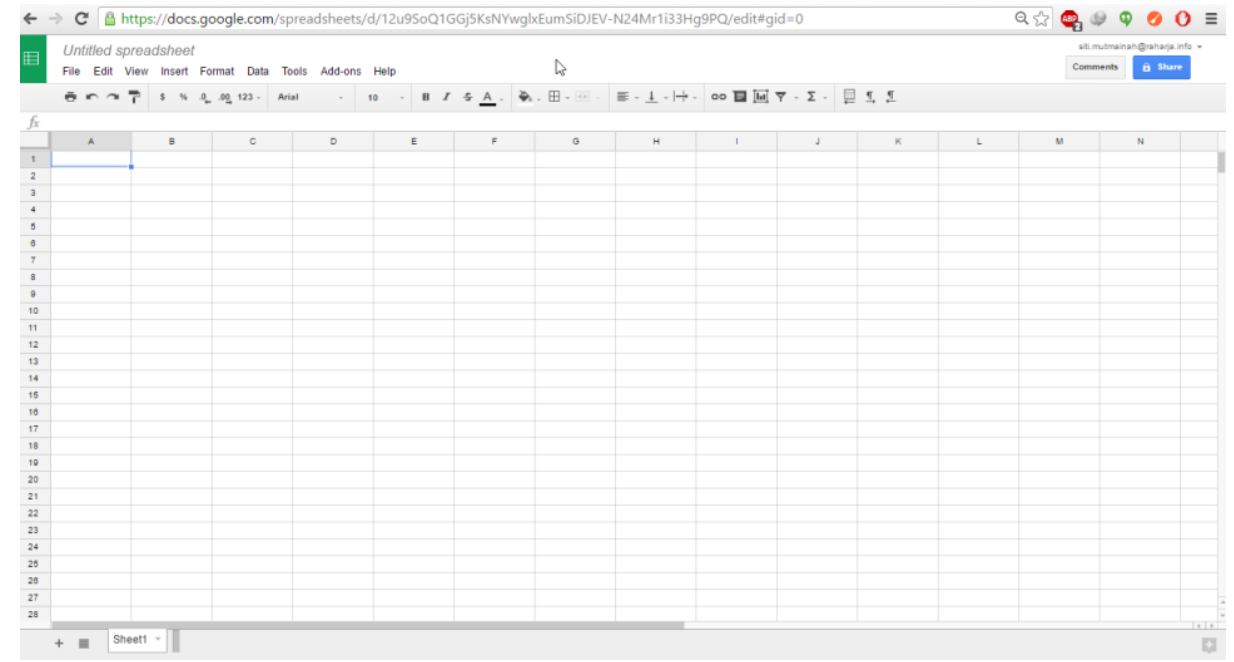

Gambar 4 . Rinfo Sheet adalah salah satu aplikasi yang disediakan oleh Google yang memilik fungsi kurang lebuh sama dengan Microsoft Exel

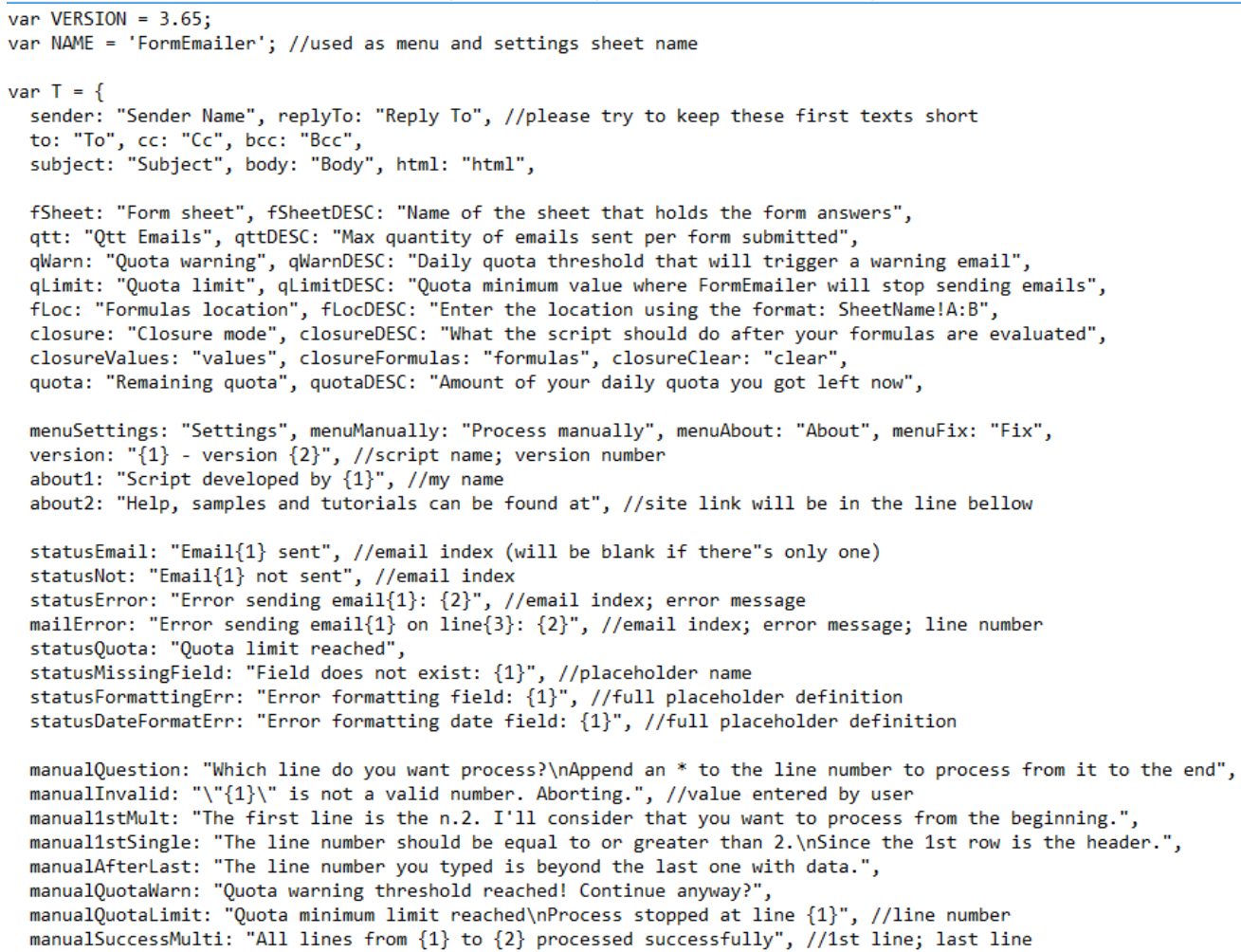

Gambar 5. Tampilan Script Form Emailer pada Spreadsheet

Script Form Emailer pada Spreadsheet berfungsi untuk mengatur adanya email notifikasi agar mahasiswa yang sudah mengisi kuesioner online secara otomatis mendapat email notifikasi. 
FormEmailer Settings

\begin{tabular}{|c|c|c|c|}
\hline Email1 & Email2 & Advanced & \\
\hline \multicolumn{4}{|c|}{ Answers placeholders: JADWAL PETUGAS KUESIONER SEl } \\
\hline Sender Name: & Formen & ailer & \multirow{3}{*}{$\begin{array}{l}\leftarrow \text { insert placeholder } \\
\leftarrow \text { insert placeholder } \\
\leftarrow \text { insert placeholder }\end{array}$} \\
\hline To: & sitimutr & ainah@raharja.info & \\
\hline & kuesion & r akademik semester genap 2015/2016 & \\
\hline $\begin{array}{l}\text { Body: } \\
\text { html }\end{array}$ & $\begin{array}{l}\text { Berikut } \\
<\mathrm{bl}> \\
<b>\mathrm{Ke} \\
<b>\mathrm{Na} \\
<b>\mathrm{Na} \\
<b>\mathrm{Pe} \\
<b>\mathrm{Pe} \\
<b>\mathrm{Pe} \\
<b>\mathrm{Pe} \\
<b>\mathrm{Pe} \\
<b>\mathrm{Pe} \\
<b>\mathrm{Pe} \\
<b>\mathrm{Pe} \\
<b>\mathrm{Pe} \\
<b>\mathrm{Pe} \\
<b>\mathrm{Pe}\end{array}$ & 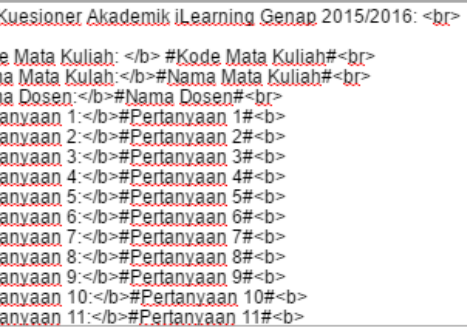 & . \\
\hline Add field: Reply & IyTOCCE & \begin{tabular}{ll|}
$c$ & Save and Close
\end{tabular} & $\uparrow$ insert placeholder \\
\hline
\end{tabular}

Gambar 6. Tampilan men-setting Form Emailer 1.

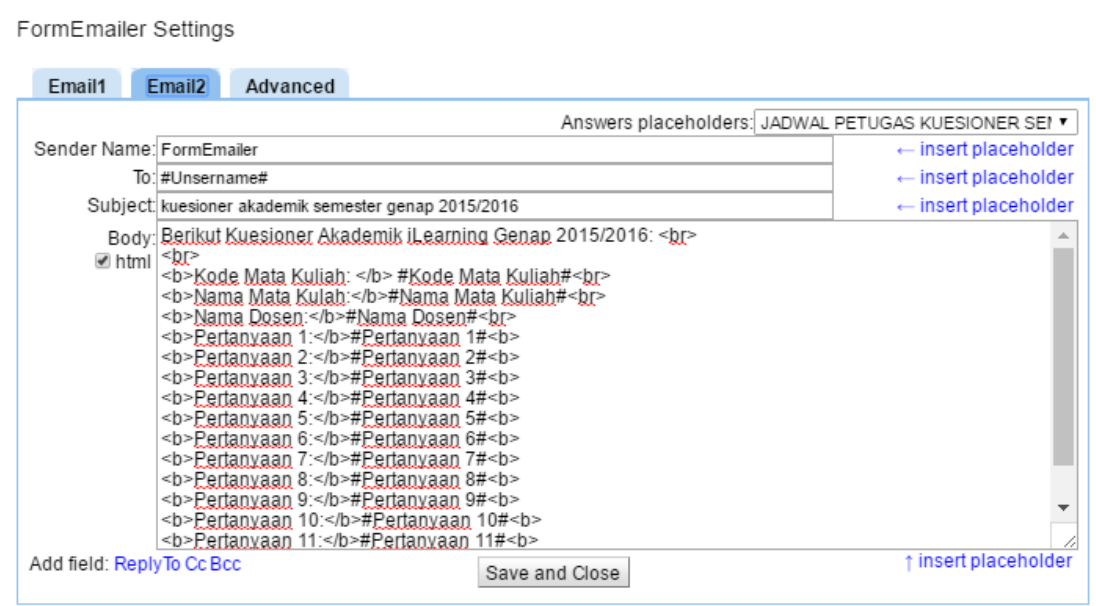

\section{Gambar 7. Tampilan men-setting Form Emailer 2.}

Dalam pembuatan form kuesioner online menggunakan Rinfo Form, harus mengatur notifikasi email kepada sispaia saja yang akan menerima notifikasi email tersebut. Setelah mengisi form kuesioner secara online, maka notifikasi akan tampil di email yang sudah admin tulis di setting Spreadsheet disini tertulis hanya 2 email saja yaitu mahasiswa yang mengisi dan admin. Berikut cara penerapan kuesioner dosen menggunakan Rinfo Form 


\section{Login Rinfo}

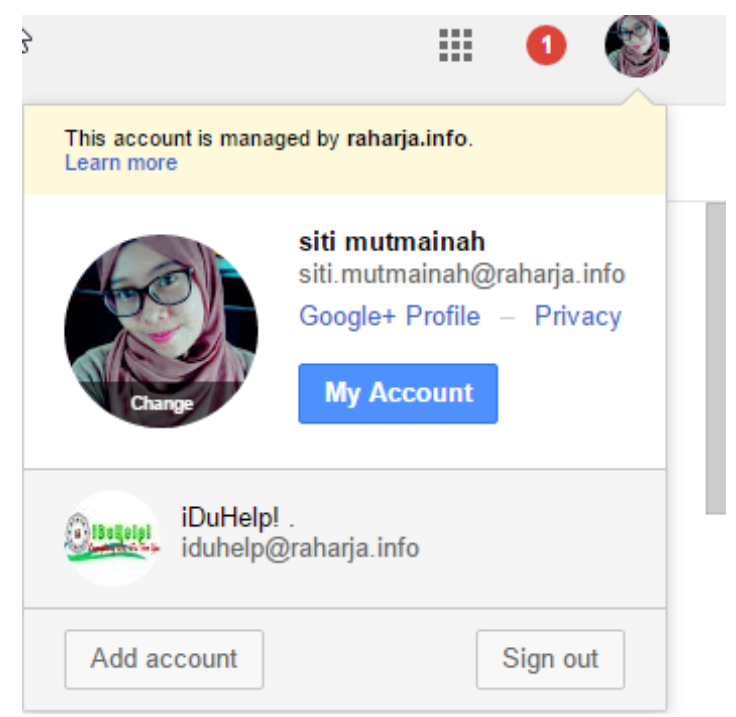

Gambar 8. Tampilan Email Rinfo

\section{Buka iDu pilih Login with Google}

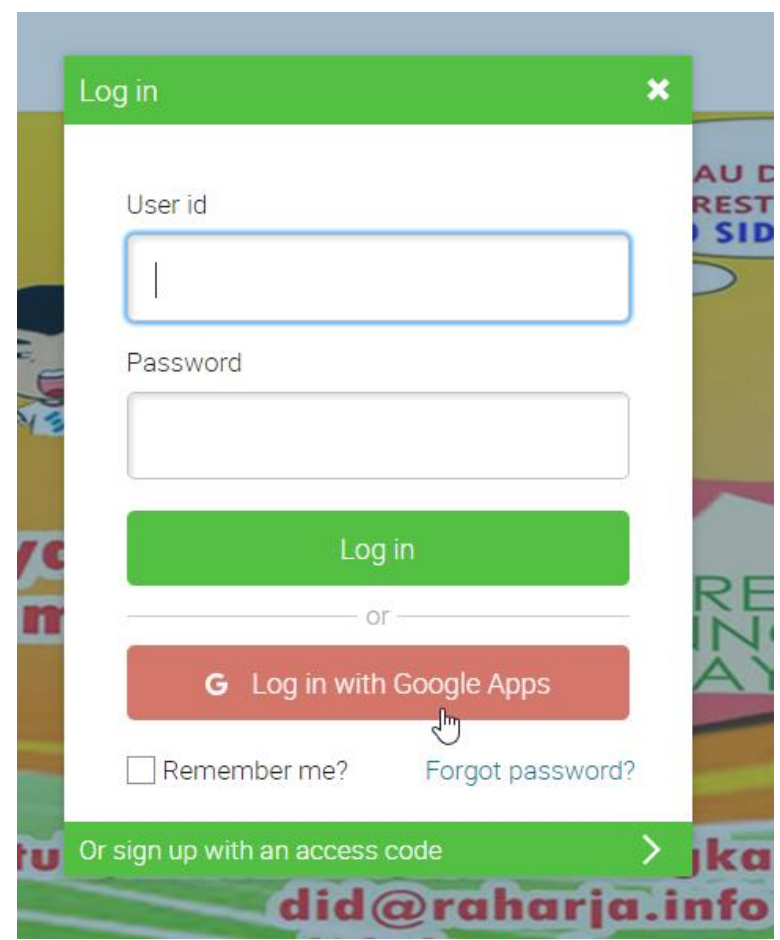

Gambar 9. Tampilan Login iDu SSO with Google

56 | Siregar - Seleksi Penyerang Utama Menggunakan K-Means Clustering ... 


\section{Pilih kelas yang akan diisi Kuesioner Dosen}

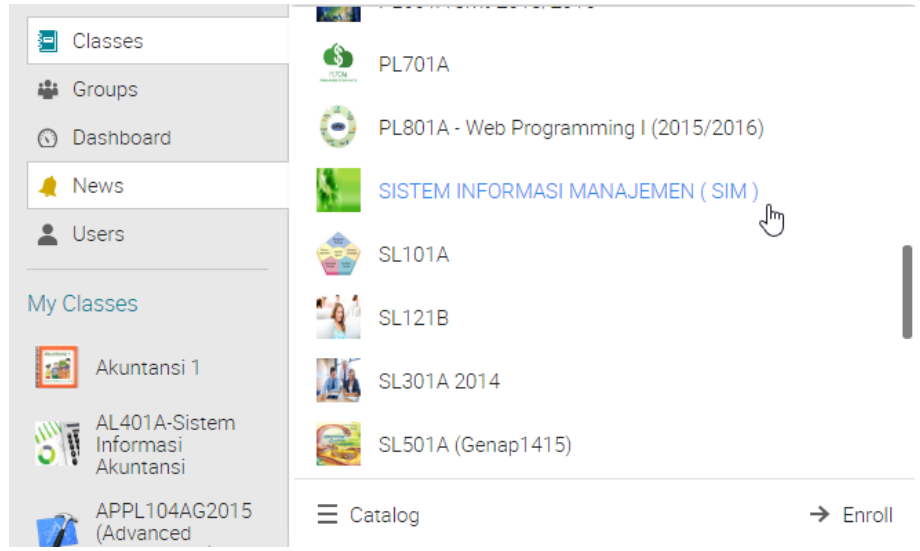

Gambar 10. Tampilan kode kelas iLearning

\section{Pilih Assisment Kuesioner}

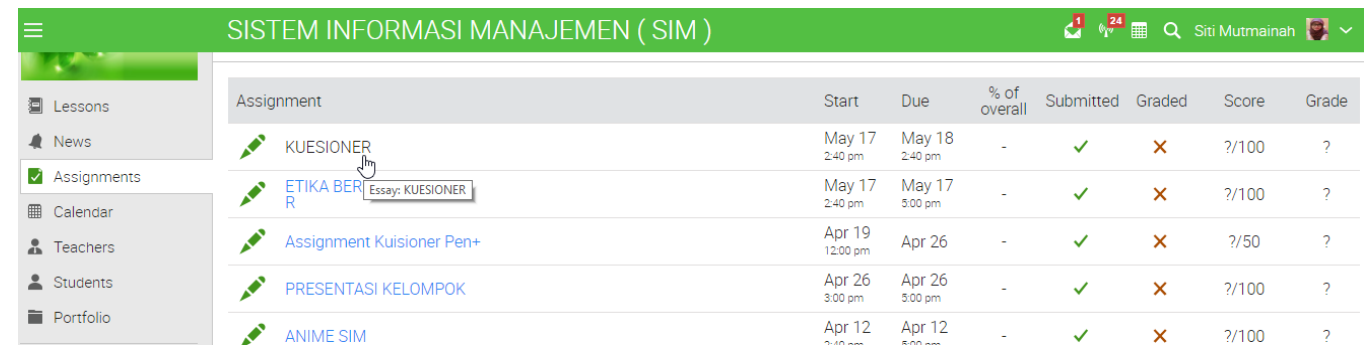

Gambar 11. Tampilan Assigment

\section{Klik Link Kuesioner yang tersedia pada Instructions}

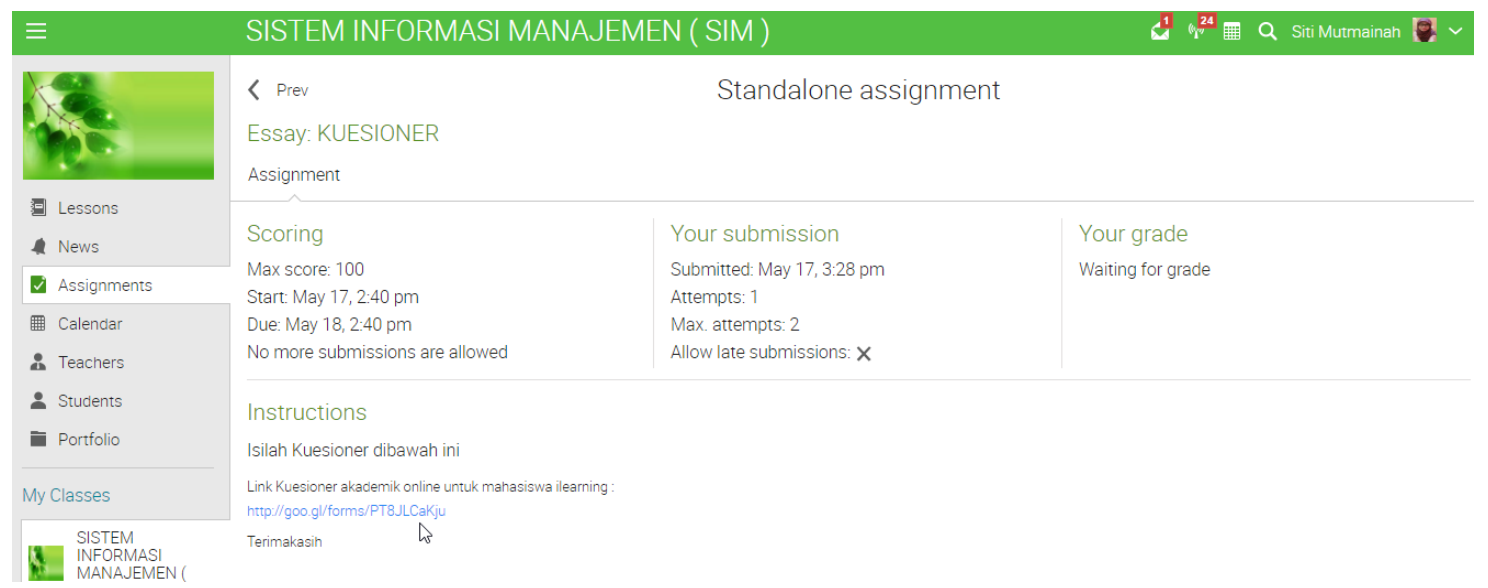

Gambar 12. Tampilan Instructions

57 | Siregar - Seleksi Penyerang Utama Menggunakan K-Means Clustering ... 


\section{Tampilan Kuesioner Online Rinfo Form}

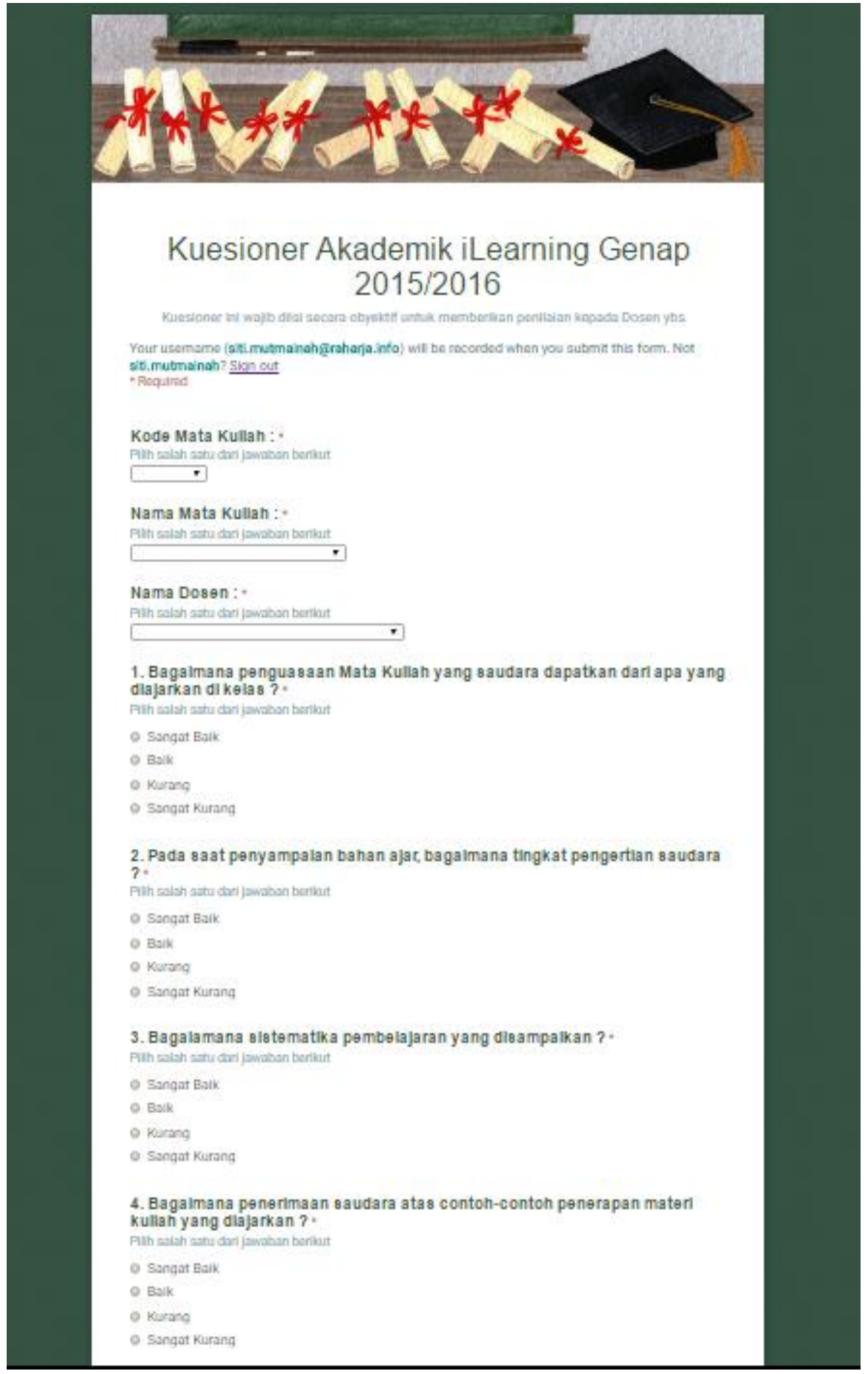

Gambar 13. Tampilan Form Kuesioner Rinfo Form 
Pada form kuesioner dosen secara online yang menggunakan Rinfo Form ini terdiri dari kode mata kuliah, nama mata kuliah, nama dosen, terdapat 12 pertanyaan dan 1 kolom saran setelah itu mahasiswa bisa submit.

\section{Tampilan akhir setelah mengisi Form Kuesioner Online}

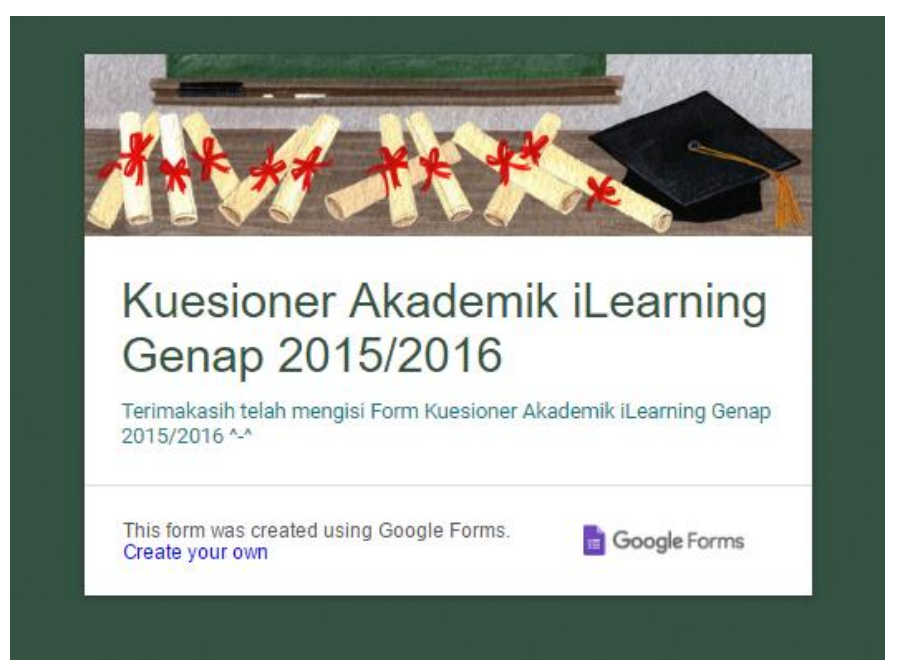

Gambar 14. Tampilan akhir Form Dosen

Setelah mengisi semua pertanyaan pada kuesioner dosen tersebut dan klik submit maka akan tampil, tampilan seperti diatas.

\section{HASIL DAN PEMBAHASAN}

Ditinjau dari segi waktu mind mapping juga dapat mengefisienkan penggunaan waktu dalam mempelajari suatu informasi. Hal ini utamanya disebabkan karena metode ini dapat menyajikan gambaran menyeluruh atas suatu hal, dalam waktu yang lebih singkat. Dengan kata lain, mind mapping mampu memangkas waktu belajar dengan mengubah pola pencatatan linear yang memakan waktu menjadi pencatatan yang efektif yang sekaligus langsung dapat dipahami oleh individu. 


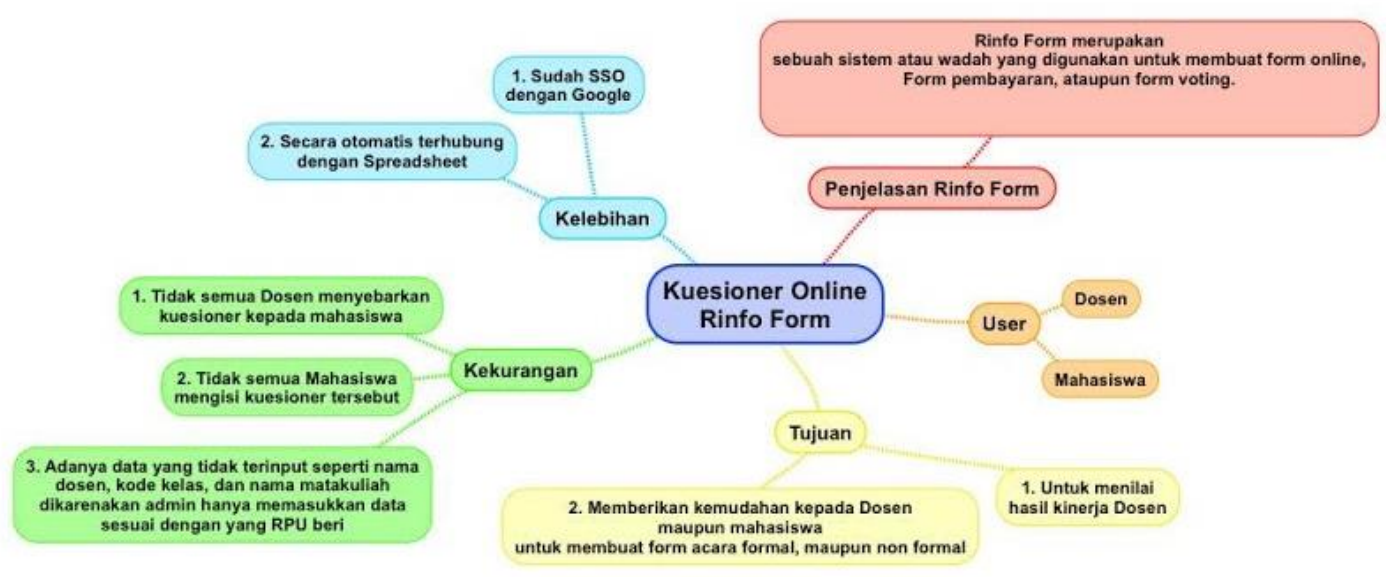

Gambar 15. Mindmap Kuesioner Online Rinfo Form

\subsection{Flowchart}

Flowchart adalah penggambaran secara grafik dari langkah-langkah dan uruturutan prosedur dari suatu program ([Menurut Adelia 2011:116]). Flowchart program dalam pemecahan masalah merupakan keterangan yang lebih rinci tentang bagaimana setiap langkah program atau prosedur sesungguhnya akan dilaksakan. Flowchart ini menunjukan setiap langkah program atau prosedur dalam urutan yang tepat saat terjadi. Berikut flowchart pembayaran kuisioner online menggunakan Rinfo Form pada Perguruan Tinggi Raharja sebagai berikut :

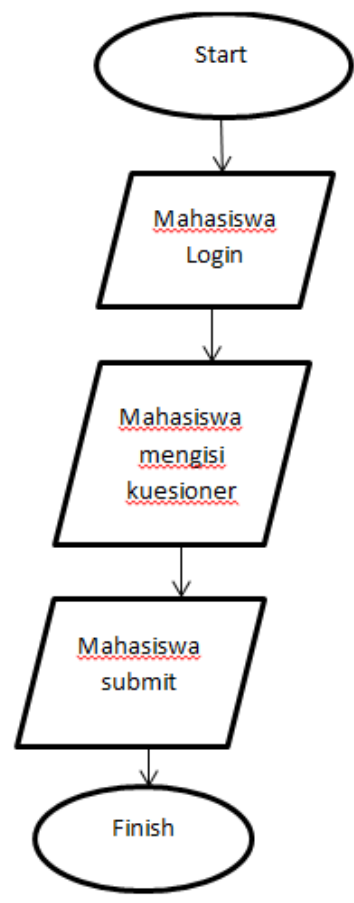

Gambar 16. Flowchart kuesioner dosen menggunakan Rinfo Form 
Gambar diatas menjelaskan proses berjalannya penyebaran dan pengisian kuesioner secara online pada Perguruan Tinggi Raharja :

1. Dosen login iDu

2. Dosen memberikan assigment

3. Dosen submit

4. Mahasiswa menerima assigment di iDu

5. Mahasiswa login iDu

6. Mahasiswa mengisi form kuesioner dosen

7. Mahasiswa submit form kuesiner dosen

Sehingga dapat disimpulkan bahwa proses kuesioner dosen secara online pada Perguruan Tinggi Raharja dengan cara menggunakan Rinfo Form lebih efektif dan. Dan dari gambar di atas dapat dijabarkan bahwa hal yang pertama dilakukan oleh dosen adalah login ke iDu, lalu dosen memasukkan link kuisioner kedalam assigmet kelas, lalu dosen submit. Setelah itu mahasiswa login iDu, mahasiswa mendapatkan assigment kuesioner dari dosen dan mahasiswa membuka link kuisioner dan mahasiwa mengisi Form Kuesioner tersebut. Setelah mengisi mahasiswa akan mendapat pemberitahuan by email karena sudah mengisi Form Kuesioner secara online.

\subsection{Listing Program}

Kuesioner online digunakan sebagai sarana form yang memanfaatkan Rinfo Transformation sebagai notifikasi email ke 2 (dua) pihak yaitu mahasiswa dan Admin , sehingga listing program yang ditampilkan adalah form emailer pada Rinfo sheets. Berikut listing programnya : 
to: "To", cc: "Cc", bcc: "Bcc",

subject: "Subject", body: "Body", html: "html",

fSheet: "Form sheet", fSheetDESC: "Name of the sheet that holds the form answers", qtt: "Qtt Emails", qttDESC: "Max quantity of emails sent per form submitted",

qWarn: "Quota warning", qWarnDESC: "Daily quota threshold that will trigger a warning email",

qLimit: "Quota limit", qLimitDESC: "Quota minimum value where FormEmailer will stop sending emails",

fLoc: "Formulas location", fLocDESC: "Enter the location using the format: SheetName!A:B", closure: "Closure mode", closureDESC: "What the script should do after your formulas are evaluated",

closureValues: "values", closureFormulas: "formulas", closureClear: "clear",

quota: "Remaining quota", quotaDESC: "Amount of your daily quota you got left now", menuSettings: "Settings", menuManually: "Process manually", menuAbout: "About", menuFix:

"Fix",

version: " $\{1\}$ - version $\{2\}$ ", //script name; version number

about 1: "Script developed by $\{1\}$ ", //my name

about2: "Help, samples and tutorials can be found at", //site link will be in the line bellow

statusEmail: "Email $\{1\}$ sent", //email index (will be blank if there"s only one)

statusNot: "Email $\{1\}$ not sent", //email index

statusError: "Error sending email $\{1\}:\{2\}$ ", //email index; error message

mailError: "Error sending email $\{1\}$ on line $\{3\}:\{2\}$ ", //email index; error message; line number statusQuota: "Quota limit reached",

statusMissingField: "Field does not exist: $\{1\}$ ", //placeholder name

statusFormattingErr: "Error formatting field: $\{1\}$ ", //full placeholder definition

statusDateFormatErr: "Error formatting date field: $\{1\}$ ", //full placeholder definition

manualQuestion: "Which line do you want process? InAppend an * to the line number to process from it to the end",

manualInvalid: "\" $\{1\} \backslash$ " is not a valid number. Aborting.", //value entered by user

manual1stMult: "The first line is the n.2. I'll consider that you want to process from the

beginning.",

manual1stSingle: "The line number should be equal to or greater than 2.InSince the 1 st row is

the header.",

manualAfterLast: "The line number you typed is beyond the last one with data.",

manualQuotaWarn: "Quota warning threshold reached! Continue anyway?",

manualQuotaLimit: "Quota minimum limit reached \nProcess stopped at line $\{1\}$ ", //line number 


\subsection{Implementasi}

Rinfo Form telah di implementasikan pada Perguruan Tinggi Raharja sebagai wadah untuk membuat kuesioner secara online

\section{A. Tampilan Form Kuesioner Dosen iLearning yang dapat digunakan oleh mahasiswa}

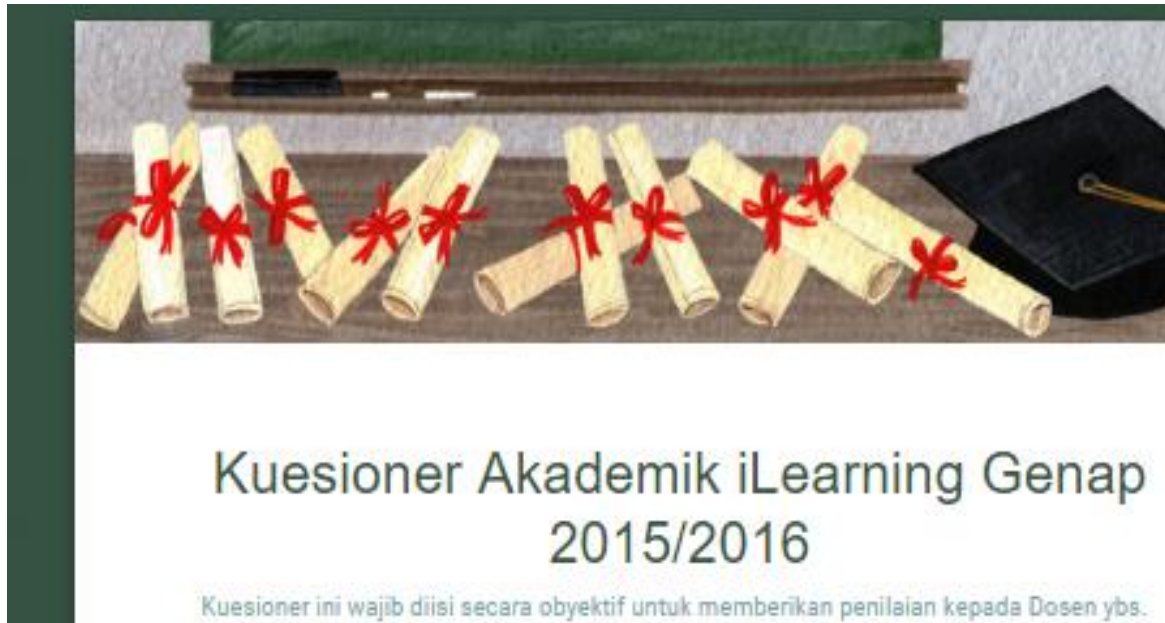

Your username (siti.mutmainah@raharja.info) will be recorded when you submit this form. Not siti.mutmainah? Sign out

* Required

Kode Mata Kuliah : *

Pilih salah satu deri jawaban berikut -

Nama Mata Kuliah : *

Pilih salah satu dari jawaban berikut

Nama Dosen : *

Pilih salah satu dari jawaban berikut

1. Bagaimana penguasaan Mata Kuliah yang saudara dapatkan dari apa yang diajarkan di kelas ? *

Pilih salah satu dari jawaban berikut
- Sangat Baik
- Baik
Kurang
- Sangat Kurang

2. Pada saat penyampaian bahan ajar, bagaimana tingkat pengertian saudara ?

Pilih salah satu dari jawaban berikut

- Sangat Baik

Baik

A Kurano

63 | Siregar-Seleksi Penyerang Utama Menggunakan K-Means Clustering ... 
Gambar 18. Tampilan Form Kuesioner Dosen

Pada gambar diatas adalah tampilan Form untuk mahasiswa, langkah pertama untuk mengisi Form adalah login melalui Rinfo Form.

\section{B. Tampilan Respondes Kuesioner Dosen}

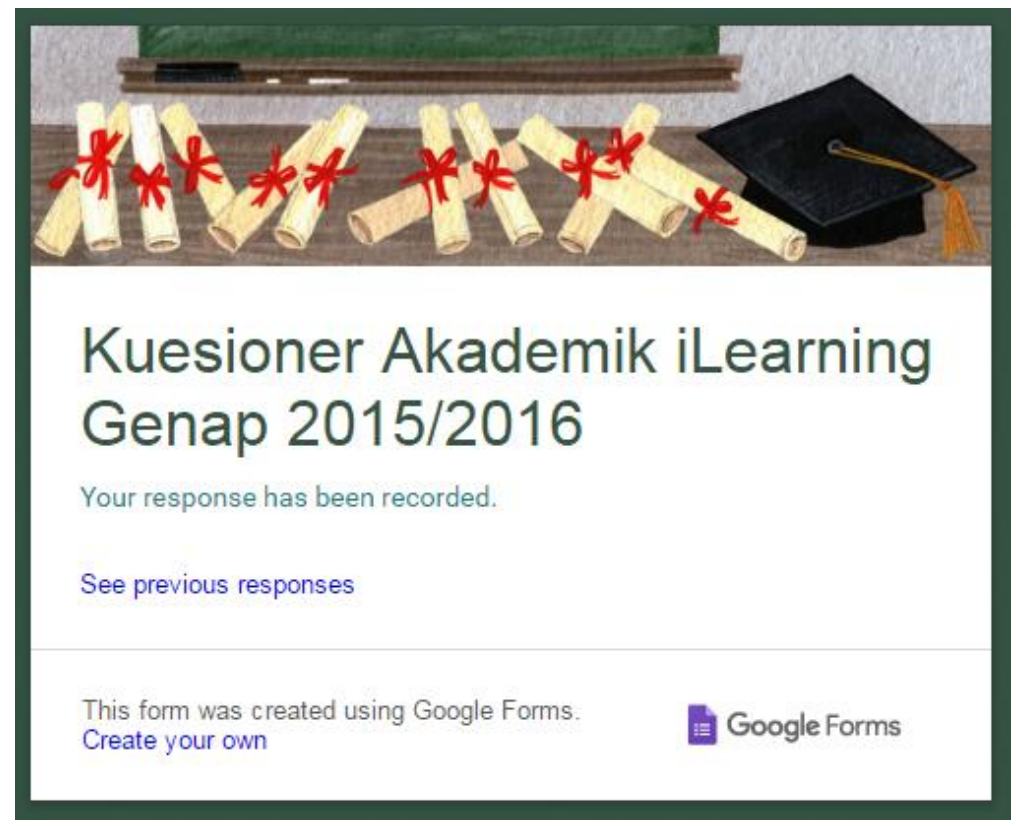

Gambar 19 diatas : Resposnded Form Dosen

Setelah mengisi semua pertanyaan pada kuesioner dosen pada Rinfo Form dan klik submit maka akan muncul tampilan seperti gambar diatas.

\section{Tampilan notifikasi menggunakan form emailer}




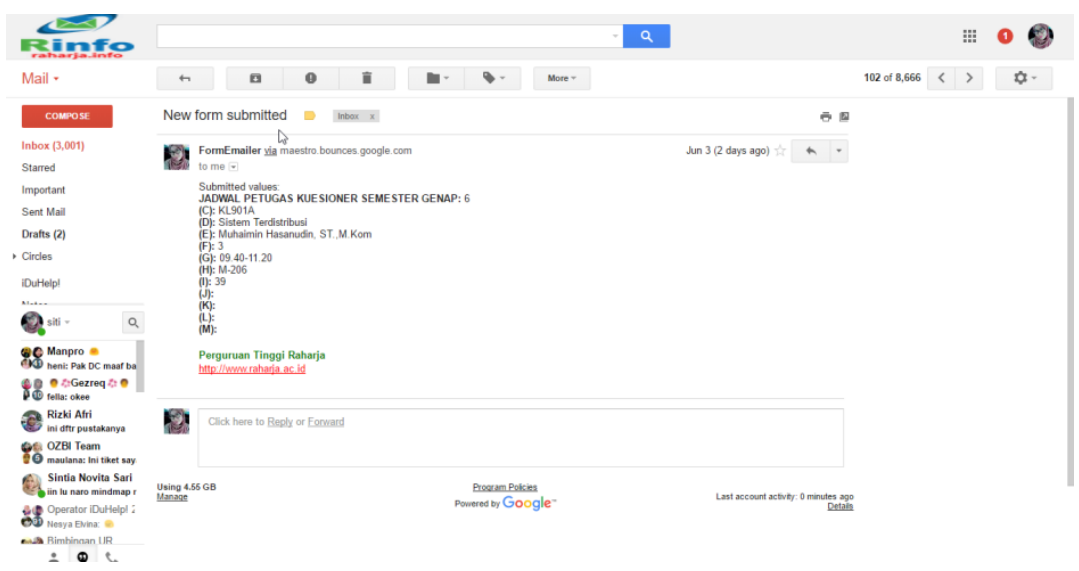

Gambar 20 diatas : Tampilan notifikasi menggunakan form emailer

\section{Tampilan View Responded Form Dosen}

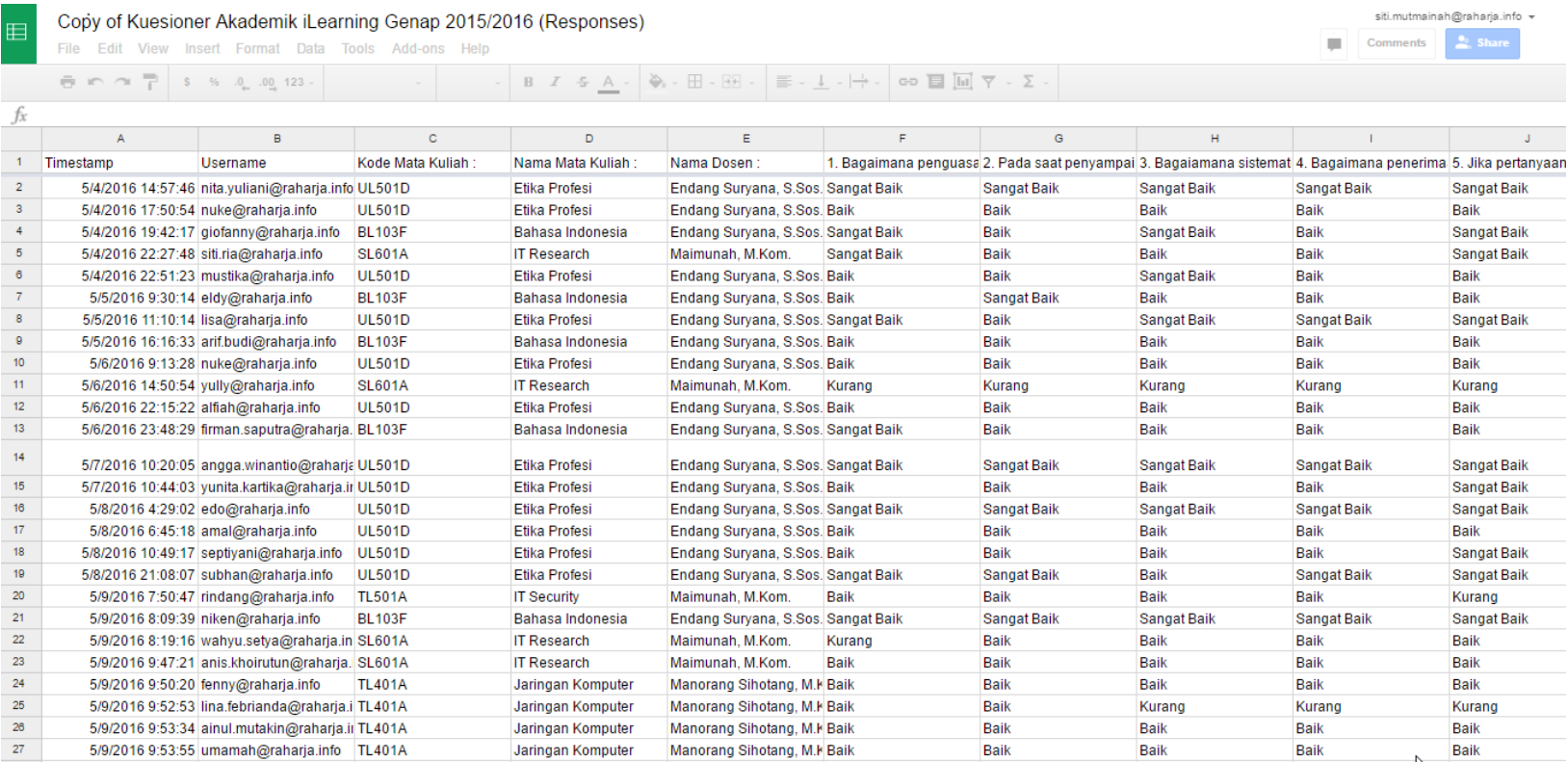

Gambar 21 diatas : Tampilan View Responded Form Dosen

\section{KESIMPULAN}

Dengan demikian disimpulkan sistem Rinfo Form sangat memaksimalkan dalam pengisian kuesioner secara online, setelah admin mendapatkan data lengkap dari RPU, admin segera menginput data didalam form kuesioner online. dan dengan di gunakannya Form Emailer pada Rinfo Form ini memudahkan admin maupun pengguna karena dengan digunakannya Form Emailer otomatis admin dan mahasiswa akan mendapatkan email pemberitahuan telah mengisi Form online tersebut. Dan untuk adminpun akan mendapatkan email pemberitahuan tentang siapa saja yang sudah mengisi form kuesioner online tersebut. Rinfo Form juga sudah terhubung dengan 
spreadsheet jika spreadsheet terkait dengan bentuk, tanggapan otomatis akan dikirimkan ke spreadsheet . jika tidak pengguna dapat melihat di ringkasan tanggapan, halaman dapat di akses dari menu tanggapan.

\section{SARAN}

Masih adanya Mahasiswa yang tidak mengisi Kuesioner Dosen tersebut, dan juga adanya Dosen yang tidak menyebarkan atau share it kuesioner tersebut kepada Mahasiswa, adanya Data Dosen yang tidak terinput dikarenakan admin hanya menulis Data lengkap yang RPU berikan. Dan Rinfo juga tidak menyediakan Fitur untuk membuat atau mengunggah contoh pertanyaan yang ingin dibuat

\section{DAFTAR PUSTAKA}

[1] Kenney (2011). "Using Google Forms to Schedule Classes in Your Library".

[2] Taylor Laura dan Kristen Doehlr (2014). "Using online surveys to promote and assess learning".

[3] Andri Heryandi (2012). "Pembangunan Sistem Informasi Pengisian Survey Evaluasi Perkuliahan Online di Universitas Komputer Indonesia”.

[4] Banias "Can we use sport, web 2.0 and social \& informal learning to develop \& enhance social competences?"

[5] Reny Sari Dewi, A. Holil Noor Ali, dan Hanim Maria Astuti (2012). dalam karya ilmiah yang berjudul "Analisis Pengaruh Kualitas Informasi pada Kuesioner Indeks Pengajar Dosen Online Terhadap Kepuasan Pengguna”.

[6] Kartika (2015) dengan judul penelitian yaitu "Penerapan Technology Acceptance Model pada Aplikasi Edmodo di Universitas Ciputra Surabaya menggunakan Analisis Jalur".

[7] Slamet, Jumar. "Otak-Atik Google Form Guna Pembuatan Kuesioner Kepuasan Pemustaka". Info persadha 14.1 (2016):21-35. 